\title{
Abstract
}

\section{Low Power Multisensors for Selective Gas Detection ${ }^{\dagger}$}

\author{
Virginie Martini *(D), Khalifa Aguir $(\mathbb{D}$, Bruno Lawson and Marc Bendahan
}

check for

updates

Citation: Martini, V.; Aguir, K.;

Lawson, B.; Bendahan, M. Low Power Multisensors for Selective Gas Detection. Eng. Proc. 2021, 6, 89. https://doi.org/10.3390/

I3S2021Dresden-10151

Academic Editors:

Gianaurelio Cuniberti and

Larysa Baraban

Published: 17 May 2021

Publisher's Note: MDPI stays neutral with regard to jurisdictional claims in published maps and institutional affiliations.

Copyright: (c) 2021 by the authors. Licensee MDPI, Basel, Switzerland. This article is an open access article distributed under the terms and conditions of the Creative Commons Attribution (CC BY) license (https:/ / creativecommons.org/licenses/by/ $4.0 /)$.
Aix Marseille Univ., Université de Toulon, CNRS, IM2NP, 13288 Marseille, France; khalifa.aguir@im2np.fr (K.A.); bruno.lawson@im2np.fr (B.L.); marc.bendahan@im2np.fr (M.B.)

* Correspondence: virginie.martini@im2np.fr

† Presented at the 8th International Symposium on Sensor Science, 17-28 May 2021; Available online: https://i3s2021dresden.sciforum.net/.

Abstract: The aim of this work is the realization of a generic gas multisensor device based on MOX sensitive layer. We designed and modeled a novel detection system with several heating zones associated with three sensors supported on a membrane with a few micrometers of thickness. The design was optimized to overcome the problems of response stability and selectivity and to reduce power consumption. The heat repartition and the power consumption in relation to the membrane thickness were studied by finite element simulations. The results show that a membrane thickness of $4 \mu \mathrm{m}$ decreases the heater temperature by more than $100 \mathrm{~K}$ versus $2 \mu \mathrm{m}$ thickness. Ethanol detection performances were studied. The thermoelectrical characterization concluded that the three detection areas can be heated at $533 \mathrm{~K}$ with a power of $53 \mathrm{~mW}$. One sensor was tested in ethanol. The sensor response in $1 \mathrm{ppm}$ and $100 \mathrm{ppm}$ of ethanol in a 50\% relative humidity atmosphere was 1.4 and 9.2, respectively. We demonstrated that this detection device can detect ethanol with high sensitivity and stability in dry and humid air with reduced power consumption resulting in $18 \mathrm{~mW}$ per sensor.

Keywords: multisensors; gas sensors; microhotplate; MOX sensors; air quality

Supplementary Materials: The presentation file is available at https:/ /www.mdpi.com/article/10.3 390/I3S2021Dresden-10151/s1.

Institutional Review Board Statement: Not applicable. 